\title{
Tracking the process of data use professional development interventions for instructional improvement: A systematic literature review
}

Citation for published version (APA):

Ansyari, M. F., Groot, W., \& de Witte, K. (2020). Tracking the process of data use professional development interventions for instructional improvement: A systematic literature review. Educational Research Review, 31(November 2020), [100362]. https://doi.org/10.1016/j.edurev.2020.100362

Document status and date:

Published: 17/11/2020

DOI:

10.1016/j.edurev.2020.100362

Document Version:

Publisher's PDF, also known as Version of record

Document license:

Taverne

Please check the document version of this publication:

- A submitted manuscript is the version of the article upon submission and before peer-review. There can be important differences between the submitted version and the official published version of record.

People interested in the research are advised to contact the author for the final version of the publication, or visit the DOI to the publisher's website.

- The final author version and the galley proof are versions of the publication after peer review.

- The final published version features the final layout of the paper including the volume, issue and page numbers.

Link to publication

\footnotetext{
General rights rights.

- You may freely distribute the URL identifying the publication in the public portal. please follow below link for the End User Agreement:

www.umlib.nl/taverne-license

Take down policy

If you believe that this document breaches copyright please contact us at:

repository@maastrichtuniversity.nl

providing details and we will investigate your claim.
}

Copyright and moral rights for the publications made accessible in the public portal are retained by the authors and/or other copyright owners and it is a condition of accessing publications that users recognise and abide by the legal requirements associated with these

- Users may download and print one copy of any publication from the public portal for the purpose of private study or research.

- You may not further distribute the material or use it for any profit-making activity or commercial gain

If the publication is distributed under the terms of Article 25fa of the Dutch Copyright Act, indicated by the "Taverne" license above, 


\title{
Tracking the process of data use professional development interventions for instructional improvement: A systematic literature review ${ }^{\text {it }}$
}

\author{
Muhammad Fauzan Ansyari ${ }^{\text {a,b, }}{ }^{*}$, Wim Groot ${ }^{a}$, Kristof De Witte ${ }^{\text {a,c }}$ \\ ${ }^{\text {a }}$ Maastricht Graduate School of Governance, Maastricht University, Minderbroedersberg 4-6, 6211 LK, Maastricht, the Netherlands \\ ${ }^{\mathrm{b}}$ Faculty of Education and Teacher Training, UIN Sultan Syarif Kasim Riau, Jln. HR. Soebrantas No. 155, 28293, Pekanbaru, Riau, Indonesia \\ ${ }^{\mathrm{c}}$ Leuven Economics of Education Research, Faculty of Economics and Business, KU Leuven, Naamsestraat 69, 3000, Leuven, Belgium
}

\section{A R T I C L E I N F O}

\section{Keywords:}

Data use

Professional development intervention (PDI)

Teacher outcomes

Student outcomes

\begin{abstract}
A B S T R A C T
This paper investigates the evidence on the effects of data use professional development interventions (PDIs) on teacher and student outcomes through a systematic literature review. More specifically, it focuses on the key features of data use PDIs, the practices of data use, and its effects on teacher and student outcomes. To that end, we propose a framework for evaluating data use PDIs that moves from the interventions themselves (input) to the practices of data use (process) and finally the outcomes (output). The framework is used as the theoretical underpinning of this review. The results provide insights into the importance of incorporating some or all key PD features. The process of data use is viewed in this paper not only as an improvement strategy with a three-part interrelated and cyclical process of intentionally using data to inform instruction but as a constructivist learning process as well. Data use PDIs have promising results on teacher satisfaction, data literacy, attitudes and beliefs, as well as student subject-related outcomes. However, the findings also reveal that the effects on student outcomes are mediated by teacher outcomes, practices of data use and instructional changes. Overall, despite those findings, there is no evidence in the studies that PD features, teacher outcomes, practices of data use and instructional changes were, respectively, evaluated to support claims on their effects on student outcomes.
\end{abstract}

Using data through careful processes to inform actions is believed to contribute to school performance, improve school conditions, and thereby potentially enhances student learning (Schildkamp, Poortman, Luyten, \& Ebbeler, 2017). However, it does not mean that data can solve all educational problems at different levels since its effectiveness depends on many influencing factors (e.g., Coburn \& Turner, 2011; Schildkamp \& Poortman, 2015). Using data to inform decision making for such purposes is commonly termed "data use", "data-based decision making" (Carlson, Borman, \& Robinson, 2011; Lai \& Schildkamp, 2013), "data-informed decision making" (Shen \& Cooley, 2008), or "data-driven decision making” (Ikemoto \& Marsh, 2007; Mandinach, 2012; Wohlstetter, Datnow, \& Park, 2008). In this study, the term "data use" is used and it refers to a similar concept as the other terms. Data use in this study is defined as "systematically analysing existing data resources within the school, applying outcomes of analyses to innovate teaching, curricula, and

\footnotetext{
This research was sponsored by the 5000-Doctor Overseas Programme, Ministry of Religious Affairs Republic of Indonesia.

* Corresponding author. Muhammad Fauzan Ansyari, Maastricht Graduate School of Governance, Maastricht University, Minderbroedersberg 4-6, 6211 LK, Maastricht, the Netherlands.

E-mail addresses: m.f.ansyari@uin-suska.ac.id, fauzan.ansyari@maastrichtuniversity.nl (M.F. Ansyari).
} 
Table 1

Selected studies for the review.

\begin{tabular}{|c|c|c|c|c|c|c|c|c|}
\hline \multirow{2}{*}{ No } & \multirow[t]{2}{*}{ Study Author } & \multirow[t]{2}{*}{ Country } & \multirow[t]{2}{*}{ Scope } & \multirow[t]{2}{*}{ Edu. Level } & \multirow{2}{*}{$\begin{array}{l}\text { Intervention } \\
\text { Lenght }\end{array}$} & \multirow[t]{2}{*}{ Outcome Variable } & \multicolumn{2}{|l|}{ Research Design } \\
\hline & & & & & & & Method & Sample (N) \\
\hline 1. & $\begin{array}{l}\text { van der Scheer } \\
\text { and Visscher } \\
(2018)\end{array}$ & $\begin{array}{l}\text { The } \\
\text { Netherlands }\end{array}$ & National & Primary & 1 year & $\begin{array}{l}\text { Student } \\
\text { mathematical } \\
\text { achievement }\end{array}$ & $\begin{array}{l}\text { Randomized } \\
\text { controlled trial }\end{array}$ & $\begin{array}{l}\text { Experimental group } \\
\text { (19 classes; } 25 \\
\text { teachers) and control } \\
\text { group ( } 29 \text { classes, } 33 \\
\text { teachers) }\end{array}$ \\
\hline 2. & $\begin{array}{l}\text { Reeves and } \\
\text { Chiang (2018) }\end{array}$ & U.S. & National & $\mathrm{K}-12$ & 5 days & $\begin{array}{l}\text { Self-efficacy and } \\
\text { anxiety }\end{array}$ & $\begin{array}{l}\text { Pre-test-post- } \\
\text { test } \\
\text { experimental } \\
\text { study }\end{array}$ & 25 in-service teachers \\
\hline 3. & $\begin{array}{l}\text { Kippers et al. } \\
\text { (2018) }\end{array}$ & $\begin{array}{l}\text { The } \\
\text { Netherlands }\end{array}$ & National & Secondary & 1 year & Teacher data literacy & $\begin{array}{l}\text { A single-group } \\
\text { pre-post } \\
\text { research design }\end{array}$ & 27 in-service teachers \\
\hline 4. & $\begin{array}{l}\text { van Geel et al. } \\
\text { (2017) }\end{array}$ & $\begin{array}{l}\text { The } \\
\text { Netherlands }\end{array}$ & National & Primary & 2 years & Teacher data literacy & Cohort & $\begin{array}{l}\text { The first cohort } 53 \\
\text { schools, the second } \\
\text { cohort } 48 \text { schools, } \\
1182 \text { teachers }\end{array}$ \\
\hline 5. & $\begin{array}{l}\text { Staman et al. } \\
\text { (2017) }\end{array}$ & $\begin{array}{l}\text { The } \\
\text { Netherlands }\end{array}$ & National & Primary & 2 years & $\begin{array}{l}\text { Student performance } \\
\text { in Mathematics }\end{array}$ & $\begin{array}{l}\text { Quasi- } \\
\text { experimental }\end{array}$ & $\begin{array}{l}42 \text { schools in the } \\
\text { experimental and } 42 \text { in } \\
\text { the control condition }\end{array}$ \\
\hline 6. & $\begin{array}{l}\text { van der Scheer } \\
\text { et al. (2017) }\end{array}$ & $\begin{array}{l}\text { The } \\
\text { Netherlands }\end{array}$ & National & Primary & 1 year & $\begin{array}{l}\text { Teacher } \\
\text { instructional skills }\end{array}$ & $\begin{array}{l}\text { A short- } \\
\text { interrupted } \\
\text { time series } \\
\text { research design }\end{array}$ & $\begin{array}{l}34 \text { grade } 4 \text { teachers } \\
\text { from } 30 \text { primary } \\
\text { schools }\end{array}$ \\
\hline 7. & $\begin{array}{l}\text { Ebbeler et al. } \\
\text { (2017) }\end{array}$ & $\begin{array}{l}\text { The } \\
\text { Netherlands }\end{array}$ & National & Secondary & 1.5 years & $\begin{array}{l}\text { Teacher satisfaction, } \\
\text { data literacy skills } \\
\text { and attitudes }\end{array}$ & $\begin{array}{l}\text { Quasi- } \\
\text { experimental }\end{array}$ & $\begin{array}{l}\text { Experimental }=10 \\
\text { schools, Control } 42 \\
\text { schools. A data use } \\
\text { questionnaire filled in } \\
\text { by data team schools } \\
(\mathrm{N}=9 \text { ) and } \\
\text { comparison schools ( } \\
=42) \text {, a satisfaction } \\
\text { questionnaire filled in } \\
\text { by data team } \\
\text { participants }(\mathrm{N}=55), \\
\text { pre- and post-test } \\
\text { knowledge tests filled } \\
\text { in by data team } \\
\text { participants }(\mathrm{N}=36)\end{array}$ \\
\hline 8. & $\begin{array}{l}\text { Supovitz and } \\
\text { Sirinides (2017) }\end{array}$ & U.S. & District & Elementary & 1 year & $\begin{array}{l}\text { 1) Views about the } \\
\text { importance of data } \\
\text { on teaching and } \\
\text { learning and self- } \\
\text { reported proficiency } \\
\text { to use data in } \\
\text { instruction, } \\
\text { 2) Perception of } \\
\text { learning about } \\
\text { mathematics } \\
\text { instruction and } \\
\text { understanding of } \\
\text { students' thinking, } \\
\text { 3) Teachers' } \\
\text { externally rated } \\
\text { mathematics } \\
\text { instructional } \\
\text { practice, and 4) } \\
\text { Overall mathematics } \\
\text { performance of } \\
\text { students }\end{array}$ & $\begin{array}{l}\text { Randomized } \\
\text { control trial }\end{array}$ & $\begin{array}{l}64 \text { teachers in } 27 \\
\text { professional learning } \\
\text { communities } \\
\text { (Experimental }=34 \\
\text { teachers and Control } \\
=30 \text { teachers) }\end{array}$ \\
\hline 9. & $\begin{array}{l}\text { van Kuijk et al. } \\
\text { (2016) }\end{array}$ & $\begin{array}{l}\text { The } \\
\text { Netherlands }\end{array}$ & National & Primary & 1 year & $\begin{array}{l}\text { Student reading } \\
\text { comprehension }\end{array}$ & $\begin{array}{l}\text { Quasi- } \\
\text { experimental }\end{array}$ & $\begin{array}{l}\text { experimental } \\
\text { condition }(n=420) \text {; } \\
\text { the control condition } \\
(n=399)\end{array}$ \\
\hline 10. & $\begin{array}{l}\text { Poortman and } \\
\text { Schildkamp } \\
\text { (2016) }\end{array}$ & $\begin{array}{l}\text { The } \\
\text { Netherlands }\end{array}$ & National & Secondary & 2 years & $\begin{array}{l}\text { Student } \\
\text { achievement, } \\
\text { including English }\end{array}$ & $\begin{array}{l}\text { Quasi- } \\
\text { experimental }\end{array}$ & $\begin{array}{l}10 \text { schools: each school } \\
\text { with } 4-6 \text { teachers, } 1-2 \\
\text { school leaders and a } \\
\text { quality } \\
\text { (continued on next page) }\end{array}$ \\
\hline
\end{tabular}


Table 1 (continued)

\begin{tabular}{|c|c|c|c|c|c|c|c|c|}
\hline \multirow{2}{*}{ No } & \multirow[t]{2}{*}{ Study Author } & \multirow[t]{2}{*}{ Country } & \multirow[t]{2}{*}{ Scope } & \multirow[t]{2}{*}{ Edu. Level } & \multirow{2}{*}{$\begin{array}{l}\text { Intervention } \\
\text { Lenght }\end{array}$} & \multirow[t]{2}{*}{ Outcome Variable } & \multicolumn{2}{|l|}{ Research Design } \\
\hline & & & & & & & Method & Sample (N) \\
\hline & & & & & & & & $\begin{array}{l}\text { care manager in a data } \\
\text { team. }\end{array}$ \\
\hline 11. & $\begin{array}{l}\text { van der Scheer } \\
\text { and Visscher } \\
\text { (2016) }\end{array}$ & $\begin{array}{l}\text { The } \\
\text { Netherlands }\end{array}$ & National & Primary & 2 years & Teacher self-efficacy & $\begin{array}{l}\text { Long } \\
\text { randomized } \\
\text { controlled trial }\end{array}$ & $\begin{array}{l}32 \text { teachers in } \\
\text { treatment group } 1 \text {, and } \\
28 \text { teachers in } \\
\text { treatment group } 2 .\end{array}$ \\
\hline 12. & $\begin{array}{l}\text { van Geel et al. } \\
\text { (2016) }\end{array}$ & $\begin{array}{l}\text { The } \\
\text { Netherlands }\end{array}$ & National & Primary & 2 years & $\begin{array}{l}\text { Student achievement } \\
\text { growth }\end{array}$ & $\begin{array}{l}\text { A multiple } \\
\text { single-subject } \\
\text { design }\end{array}$ & $\begin{array}{l}53 \text { Dutch primary } \\
\text { schools (1190 team } \\
\text { members) }\end{array}$ \\
\hline 13. & $\begin{array}{l}\text { Konstantopoulos } \\
\text { et al. (2013) }\end{array}$ & U.S. & State & $\mathrm{K}-8$ & 1 year & $\begin{array}{l}\text { Mathematics and } \\
\text { reading achievement } \\
\text { outcomes }\end{array}$ & $\begin{array}{l}\text { Cluster } \\
\text { randomized } \\
\text { experiment }\end{array}$ & $\begin{array}{l}35 \text { schools in the } \\
\text { treatment condition } \\
\text { and } 24 \text { schools in the } \\
\text { control condition. }\end{array}$ \\
\hline 14. & $\begin{array}{l}\text { Slavin et al. } \\
\text { (2013) }\end{array}$ & U.S. & District & $\begin{array}{l}\text { Elementary } \\
\text { and middle } \\
\text { school }\end{array}$ & 4 years & $\begin{array}{l}\text { Reading and } \\
\text { Mathematics }\end{array}$ & $\begin{array}{l}\text { Cluster- } \\
\text { randomized } \\
\text { experiment }\end{array}$ & $\begin{array}{l}2005(n=20), 2006 \\
(n=13), \text { and } 2007(n \\
=26)\end{array}$ \\
\hline 15. & $\begin{array}{l}\text { McNaughton, Lai, } \\
\text { \& Hsiao (2012) }\end{array}$ & $\begin{array}{l}\text { New } \\
\text { Zealand }\end{array}$ & National & Middle school & 3 years & $\begin{array}{l}\text { Reading } \\
\text { comprehension }\end{array}$ & $\begin{array}{l}\text { Quasi- } \\
\text { experimental }\end{array}$ & 2 clusters of schools \\
\hline 16. & $\begin{array}{l}\text { Carlson et al. } \\
\text { (2011) }\end{array}$ & U.S. & National & $\begin{array}{l}\text { Elementary, } \\
\text { middle, and } \\
\text { high school }\end{array}$ & 1 year & $\begin{array}{l}\text { Mathematics and } \\
\text { reading achievement } \\
\text { outcomes }\end{array}$ & $\begin{array}{l}\text { Cluster } \\
\text { randomized } \\
\text { trial }\end{array}$ & $\begin{array}{l}500 \text { schools within } 59 \\
\text { school districts and } 7 \\
\text { states }\end{array}$ \\
\hline 17. & Lai et al. (2009) & $\begin{array}{l}\text { New } \\
\text { Zealand }\end{array}$ & National & $\begin{array}{l}\text { Primary } \\
\text { Middle }\end{array}$ & 3 years & $\begin{array}{l}\text { Achievement in } \\
\text { reading } \\
\text { comprehension }\end{array}$ & $\begin{array}{l}\text { Quasi- } \\
\text { experimental }\end{array}$ & $\begin{array}{l}\text { Cohort } 1(n=114) \\
\text { students who were } \\
\text { Year } 4 \text { at Time } 1 ; \\
\text { Cohort } 2(n=56) \\
\text { students who were } \\
\text { Year } 5 \text { at Time } 1 \text {, and } \\
\text { Cohort } 3(n=68) \\
\text { students who were } \\
\text { Year } 6 \text { at Time } 1\end{array}$ \\
\hline
\end{tabular}

school performance, and, implementing (e.g. genuine improvement actions) and evaluating these innovations" (Schildkamp \& Kuiper, 2010, p. 482). (see Table 1)

Several studies have reported that using data to make decisions can help teachers improve instruction and help students obtain better learning outcomes (Carlson et al., 2011; Gelderblom, Schildkamp, Pieters, \& Ehren, 2016; Lai \& McNaughton, 2016; McNaughton, Lai, \& Hsiao, 2012; Lai, Wilson, McNaughton, \& Hsiao, 2014; Poortman \& Schildkamp, 2016; van Geel, Keuning, Visscher, \& Fox, 2016). Therefore, these potential impacts have triggered attention from policymakers and stakeholders in education to invest in PDIs to arm teachers with data literacy with the aim to increase student outcomes.

Although studies on data use PDIs have been conducted in many countries, such as the Focus Intervention in the Netherlands (Staman, Timmermans, \& Visscher, 2017), the Learning Schools in New Zealand (Lai, McNaughton, Amituanai-Toloa, Turner, \& Hsiao, 2009), and Centre for Data-Driven Reform in Education (CDDRE) intervention in the U.S. (Carlson et al., 2011), few attempts have been made to synthesise the effects of data use PDIs on teacher and student outcomes. For example, Faber and Visscher (2014) conducted a meta-analysis on the use of digital student monitoring systems on student performance and found an average effect size of 0.38. Marsh (2012) reviewed the evidence on effectiveness more broadly and found mixed results and levels of evidence on the effects of interventions with more evidence on educators than organisation and students. Despite those studies, research indicates, "the field still lacks definitive evidence" (Mandinach \& Gummer, 2015, p. 1) and there has been little attempt to explicitly define the model of how a data use PDI contributes to student outcomes.

Although previous studies have given insights in the effects of data use interventions (Faber \& Visscher, 2014; Marsh, 2012), they did not provide evidence on the pathways of how the interventions resulted in student outcomes. Therefore, this study reviewed the evidence on the effects of data use PDIs on teacher outcomes (e.g., knowledge, skills and attitudes) and student outcomes by studying the key features of data use PDIs, the practices of data use, and finally their effects on teacher and student outcomes. In so doing, we proposed a framework as a theoretical underpinning for this systematic review of the literature on randomized trials and quasi-experimental studies. We selected these types of studies because they can elicit causal inferences on the effects on student achievement (Whitehurst, 2012) and contribute significantly to the evidence on educational effectiveness and evaluation.

This study adds to the literature by providing a framework for evaluating data use PDIs that moves from the interventions themselves (input) to the practices of data use (process) and finally the outcomes (output). The study also uncovers that the process of data use is supportive of the systematic model proposed in the previous studies (e.g., Mandinach \& Gummer, 2016; Marsh, 2012; Schildkamp \& Poortman, 2015). However, this study provides a theoretical contribution to data use theory of action by advancing our understanding of a goal (input)-based approach and an evaluation (output)-based approach to data use. 


\section{Data use professional development pathways for instructional improvement}

Understanding the linkages of data use PDIs that move from interventions themselves to data use practices and finally outcomes is important as it can provide a foundation for understanding the pathways by which an intervention - like a data use PDI for teachers produces outcomes (Rogge, Agasisti, \& De Witte, 2017; Vanthienen \& De Witte, 2017). Desimone (2009) proposed a pathway model that explains how student outcomes improve when teachers participate in PD. This model shows interactive relationships between (a) the critical features of PD, (b) increased teacher outcomes (qualities), (c) changes in classroom practice and (d) improved student learning results (Fig. 1).

The framework illustrates interactive relationships between the different components of the PD pathways. As shown, the effects of PDIs on student outcomes are complex and not direct (Desimone, 2009; van Veen, Zwart, \& Meirink, 2012). According to Desimone (2009), a PDI with these five key features increase teacher outcomes and in turn improve classroom instruction, and eventually lead to increased student outcomes. In other words, the effects on student outcomes will happen through improved teacher outcomes, and, improved classroom learning conditions (Compen, De Witte, \& Schelfhout, 2019). These two variables, therefore, serve as the PDI impacts as well as mediating variables that facilitate student learning results. The framework also indicates several contextual factors, such as individual, school, and policy, and these factors all influence the components of the PD model.

In the component of the PD features, the framework highlights the main five features of effective PD, including content focus, active learning, coherence, duration and collective participation (Desimone, 2009; Jeanpierre, Oberhauser, \& Freeman, 2005; Johnson, Kahle, \& Fargo, 2007; Penuel, Fishman, Yamaguchi, \& Gallagher, 2007; van Veen et al., 2012; Compen et al., 2019). Content focus refers to the content necessary to improve teachers' classroom practice by focusing on subject matters, evidence-based student learning, and pedagogical content knowledge (PCK) (Compen, Schelfhout, \& De Witte, 2020; Desimone, 2009; Guskey \& Yoon, 2009; Merchie, Tuytens, Devos, \& Vanderlinde, 2016; van Veen et al., 2012). An active learning approach to PD learning activities indicates an inquiry-based learning strategy (Merchie et al., 2016; van Veen et al., 2012). It is believed that an active learning environment provides teachers with meaningful experiences, such as observing expert teachers or being observed followed by interactive feedback and discussion, reviewing student work, etc. The coherence of PD means that the PD programme is aligned with the standards, curriculum, or school and district priorities (Blank, de las Alas, \& Smith, 2008; Darling-Hammond, Hyler, \& Gardner, 2017; Desimone \& Garet, 2015). PD duration highlights both the time over which the activity is spread (e.g., one year) and the number of hours spent on the activity (Desimone, 2009; Yoon, Duncan, Lee, Scarloss, \& Shapley, 2007). Darling-Hammond et al. (2017) argued that by providing sustained duration teachers have sufficient time to learn, practice, implement, and reflect on new strategies that facilitate changes in their practice. Finally, collective participation refers to a collaboration between teachers, or between teachers and internal or external peers through which teachers have the opportunity to share ideas and observe others' practices (Darling-Hammond et al., 2017; Compen et al., 2020), and this collaboration normally occurs in teachers' professional learning communities (PLCs) (Desimone \& Garet, 2015).

Although Desimone's (2009) framework provides a fundamental PD pathway model, Merchie et al. (2016) extended it by providing additional sub-components to each component of the PD pathways. In the component of PD features, they included sub-components, such as ownership which Merchie et al. (2016) define it as the sense of belonging to the content and setup of the PD programme. In regards to the component of PD impact on teacher outcomes, the authors describe it as cognitive goals, skills, and affective goals. However, King (2014) broke this impact down into a broader categorisation which includes different personal, professional and cultural levels. This categorisation represents the complexity of teacher learning and accommodates teacher outcomes in the context of data use that is generally collaborative. Personal outcomes include affective qualities, such as efficacy, beliefs and attitudes. Professional outcomes refer to both knowledge (cognitive) and skills, that is the quality of use and understanding of new and improved knowledge and skills. The last outcomes are related to forms of collaboration and development of professional learning communities (PLCs). In the component of instructional changes, Merchie et al. (2016) divided changes into instruction strategies/practices and interaction patterns between teachers and students, among teachers and among students. According to Coburn and Turner (2011), changes can also be seen in terms of other dimensions of the classroom, such as grouping and instructional materials, or other classroom dimensions. In the last component of the PD model, although there is debate among scholars about the types of impact on student outcomes, Merchie et al. (2016) made a distinction in student learning outcomes between domain-specific, subject-related knowledge and skills (such as science achievement) and domain-general outcomes (such as students' social-emotional development and self-regulated learning). Although this outcome classification only represents knowledge and skills, it may also include affective, such as student attitudes and dispositions (King, 2014). Finally, considering such a complex model, Merchie et al. (2016) further emphasised the need for evaluating the key features of effective professional development before, during and after its implementation

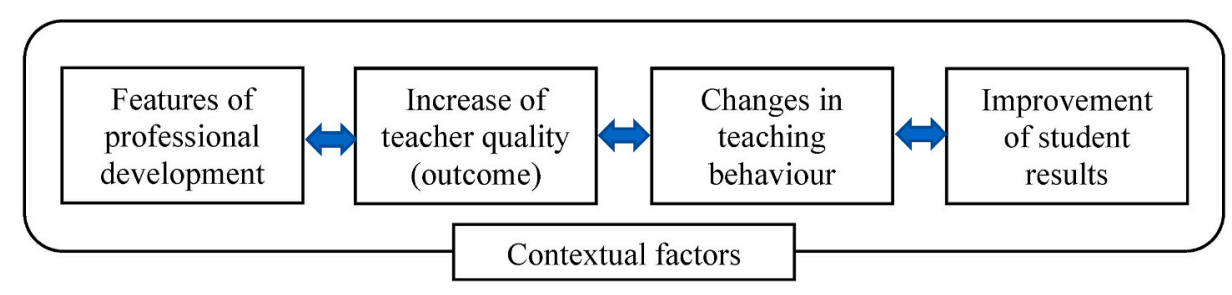

Fig. 1. Framework of studying the effects of professional development (Based on Desimone, 2009). 
of PD to ensure the impact on students' learning outcomes. It is argued that if one of the PD pathway components is weak or missing, then it becomes less likely that student learning results will improve (Yoon et al., 2007).

While the PD pathway model as proposed by Desimone (2009) with its extended sub-components (Merchie et al., 2016) has provided a valuable and evidence-based model, it requires further theoretical development and empirical exploration so that it can be used as a starting point for understanding PD pathways in various contexts. In the context of data use, the process is considered as an important component for understanding the PD pathways that move from interventions to potential outcomes (Coburn \& Turner, 2011). The authors argue that the process of data use is central to studying the pathways between data use interventions and outcomes. They further indicate that interventions interact with contextual factors to shape the underlying data use processes that have consequences for various outcomes.

The literature suggests that the process of data use usually follows a systematic, iterative and cyclic process, including establishing a goal for data use, collecting data, making sense based on data analysis and interpretation to convert data into useable information, taking action to improve teaching and learning, and evaluation (Lai \& Schildkamp, 2013; Mandinach \& Gummer, 2016; Marsh, 2012; Schildkamp \& Poortman, 2015). According to Schildkamp (2019), the first step in the process plays a crucial role because the subsequent steps should be directed toward it. Although this process is systematic, teachers in practice sometimes use data in a non-linear way as well (Schildkamp, Poortman, \& Handelzalts, 2016). It means that teachers do not always follow such systematic processes in a condition where they, for example, find their hypothesis is incorrect. In this case, they need to go back to the previous step, that is, formulating the hypothesis (Schildkamp et al., 2016).

Besides, several factors influence the effectiveness of data use, either encouraging or discouraging it. These factors revolve around data, components of data use, individuals, school and policy (e.g., Coburn \& Turner, 2011; Jimerson, Garry, Poortman, \& Schildkamp, 2019; Schildkamp, Smit, \& Blossing, 2019). The data factors are associated with the quality of the data, access and data information systems (Schildkamp et al., 2017). Teachers, for instance, need to access data from a data information system. If data in the system cannot be accessed by teachers, they find it difficult to practice data use. Another factor is related to the components of data use. According to Jimerson et al. (2019), the practice of data use can be effective if the components of data use are completely done, otherwise, it can be an obstacle. Regarding individual factors, these are related to individuals' knowledge, skills, and dispositions to both data use and effective teaching (Mandinach \& Gummer, 2016; Schildkamp et al., 2017). Mandinach and Gummer (2016) argued that data literacy for teaching needs a set of knowledge and skills both related to data use processes and effective teaching knowledge (Shulman, 1986,1987), such as pedagogical content knowledge, curriculum, etc. Moreover, school factors might include vision, leadership, and support (Schildkamp \& Poortman, 2015). A clear vision, clear goals and norms are important for teachers so that they can relate their practice to such vision or goals. Finally, research also provides evidence that policy influences data use implementation (Hoogland et al., 2016). The authors found that accountability pressure encouraged data use, while too much accountability pressure could discourage data use for genuine improvement purposes. In short, understanding how teachers use data is inseparable from the factors that contribute to its (in)effectiveness at the different levels: data, individual, school, practice, and policy.

The existing literature suggests a general pathway model for evaluating the effects of PDIs on teacher outcomes, classroom practices and student outcomes, and in the context of data use understanding the underlying processes of data use is regarded as an important

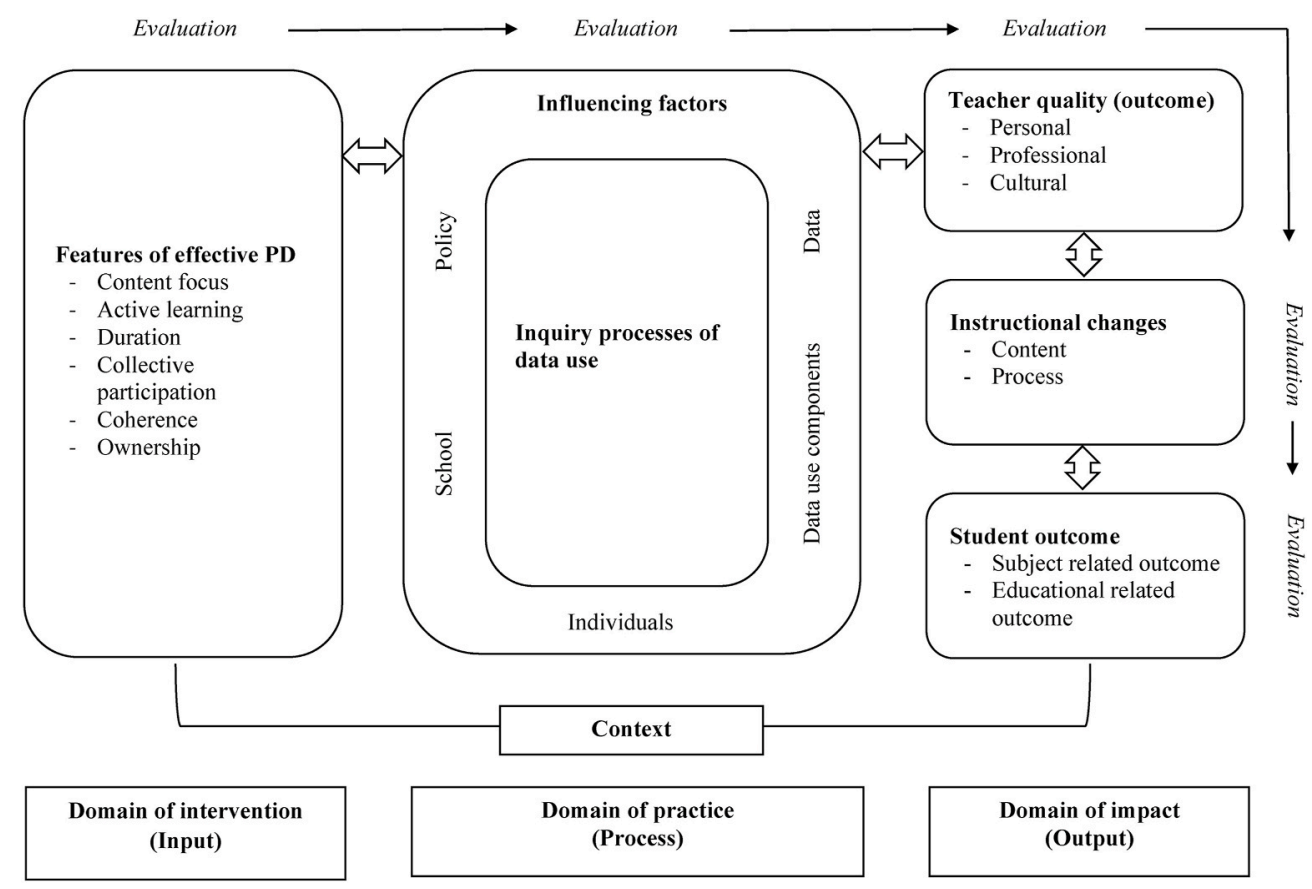

Fig. 2. General framework for evaluating the effects of data use PDIs on teacher and student outcomes used as a basis for the review. 
component of the data use pathways. Taken the above-discussed literature together, we, therefore, propose a framework whose pathways includes the interventions (input), the practices of data use (process) and finally the outcomes (output). In organising the domains of the components in the framework, we were mostly inspired by Stufflebeam's (2003) CIPP model for evaluation wherein he offered a linear process from context to input, process and product. However, we did not include context as a separate domain in our framework but integrated it in the domain of intervention. The proposed framework is presented in Fig. 2 below.

The above-discussed literature on professional development, data use and evaluation has given us more insights into how data use PDIs contributes to teacher and student outcomes. Through this lens, data use PDIs are not understood as separate but instead as embedded in teacher practice. The figure shows how data use PDIs interact with the contexts to shape the process of data use and consequently the impacts.

In the domain of intervention (input), a data use PDI is a means to develop teacher data literacy, beliefs or attitudes towards data use, or to alter teachers' use of data in their daily instruction to improve student outcomes. Effective interventions are characterised by content focus, active learning, duration, collective participation, coherence, and ownership (Desimone, 2009; Merchie et al., 2016) and these features should be incorporated in the initial design and maintained during the intervention.

As shown in the domain of practice (process), the eight PDI features interact with contextual factors and shape the interrelated, cyclical and systematic process of data use. The (in)effectiveness of the process is influenced by data use contextual factors with regards to data (e.g., quality, access), individual (e.g., knowledge and skills, attitudes), school (e.g., vision, guiding manual/protocol), components of data use (e.g., data collection, data sense-making), and policy (e.g., accountability standard) (Coburn \& Turner, 2011; Jimerson et al., 2019; Schildkamp et al., 2019; Schildkamp et al., 2017). Despite the systematic way of using data, the process of data use can also vary in the practices. Data teams might not use data systematically in cases where they need to move forward and backwards from one step to the others (Schildkamp et al., 2016).

Furthermore, the domain of impact (output) consists of teacher outcomes, classroom conditions and student outcomes respectively. Expected results in teacher outcomes revolve around personal, professional and cultural. Classroom conditions are represented by changes in contents and instructional processes, while student outcomes can be seen in terms of increased achievement on certain subjects and other educational outcomes (Coburn \& Turner, 2011; Desimone, 2009; King, 2014; Merchie et al., 2016).

In addition, evaluation is essential in determining the impact of PDIs on certain outcomes. Therefore, evaluation should be conducted on each of the five components in the three domains of the underlying PD pathways (Merchie et al., 2016; Yoon et al., 2007). This sequential evaluation ascertains the impacts of PDIs.

Finally, the intervention is shaped by contextual factors at three different levels - individual, school, and policy. These all influence the whole PD pathways (Desimone, 2009; Merchie et al., 2016). In other words, the characteristics of teachers (e.g., age and qualification), students (e.g., self-concept), schools (e.g., culture and support) and policy demands (e.g., standards) determine how PDIs are organised.

\section{Method}

This review went through the phases recommended by Petticrew and Roberts's (2006) method for systematic reviews in social sciences. The main question is what is the evidence of the effects of comprehensive data use professional development interventions (PDIs) on teacher and student outcomes? This question has three sub-questions:

1) What features guide the design of the data use PDIs?

2) What data use processes do the teachers follow during the PDIs?

3) What effects do the PDIs have on teacher and student outcomes?

We used search terms commonly used in data use literature such as "data use", "data-based decision making", "data-driven decision making", "data-informed decision making", combined with, for example, reaction, response, satisfaction, behaviour, perception, literacy, learning, knowledge, skills, development, outcome, achievement, and performance. Initially, three databases, ERIC, Francis and Taylor Journal, and Scopus were used to search for relevant articles since they commonly host educational research articles. Our initial search resulted in 2303 articles from the three databases. We also found 20 articles in our search from additional records in other databases, namely Springer and Wiley Online Library. Therefore, the total result was 2323 articles. Before going to the analysis, we removed 292 duplicate articles, thus 2031 articles remained. We then screened the titles based on the relevance of the studies to our study topic; we excluded the titles addressing irrelevant publications, such as computer science, environmental studies, medical science, etc. We also removed titles that indicated study contexts in non-formal or informal education, literature reviews, opinions, or other non-field research studies. After removing the irrelevant publications, 261 articles remained for further analysis.

In the next step, the 261 article abstracts were screened to find out if they were eligible for this review: the articles should address data use PDIs for instructional improvement for in-service teachers in formal educational contexts at any educational level (pre-school, primary, secondary and tertiary), be peer-reviewed, published between 2009 and 2019, employ a randomized experiment or quasiexperiment for causal inferences, and be written in English. We excluded journal articles that addressed such PDIs in corporate education contexts, that raised the issues of pre-service teachers or teacher candidates, and that discussed learning with disabilities. We did not include such articles because the contexts do not have similar characteristics with regular learning, such as student characteristics. After applying these inclusion and exclusion criteria to all abstracts, 81 articles remained and the full-texts were downloaded for quality check.

To check the quality of the articles, we used Petticrew and Roberts' (2006) eleven quality criteria. The inclusion criteria were 
applied to the full-text versions of the remaining articles, which resulted in 17 eligible papers as follows.

The other 64 articles were excluded because the studies used mixed methods or qualitative methods. We only included articles with experimental or quasi/experimental methods. Finally, the full-texts of all selected articles that met our quality criteria were read indepth. We used the themes from this study framework (Fig. 2) to standardise the extraction of data from the selected studies for further analysis and interpretation. We focused on the intervention, result and discussion sections to find out and analyse key themes. The first author extracted data from the studies, while the second and third authors checked the accuracy and reliability of coding. In cases of the authors' differences or doubts, each author re-read the articles and then discussion meetings were organised to resolve any differences in the themes or coding interpretations until consensuses were reached.

Last, we analysed each component of our data use PD pathway model to ensure causal claims about the effects of data use PDIs on teacher and student outcomes. Below is the flowchart of the article search (see Fig. 3).

\section{Results}

Based on the framework, this section describes the findings concerning the features of data use PDIs, as well as data use practices and outcomes respectively.

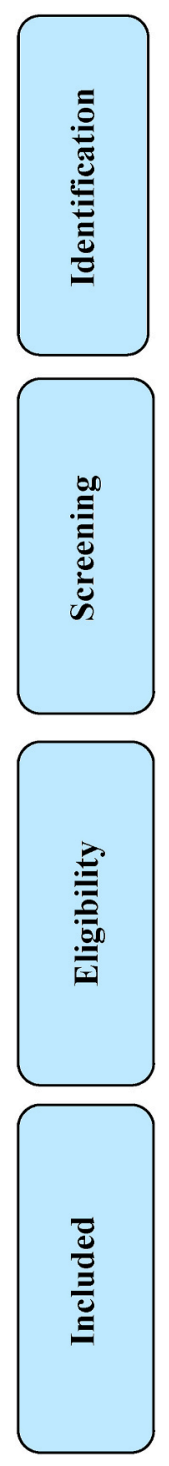

Records identified through database searching (ERIC, Tylor \& Francis, and Scopus) $(\mathrm{n}=2303)$
Additional records identified through other sources (Springer and Wiley Online Library) $(\mathrm{n}=20)$

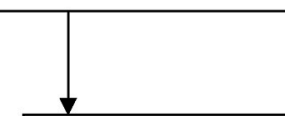

Records excluded $(\mathrm{n}=180)$

Records after duplicates (292) removed $(\mathrm{n}=2031)$

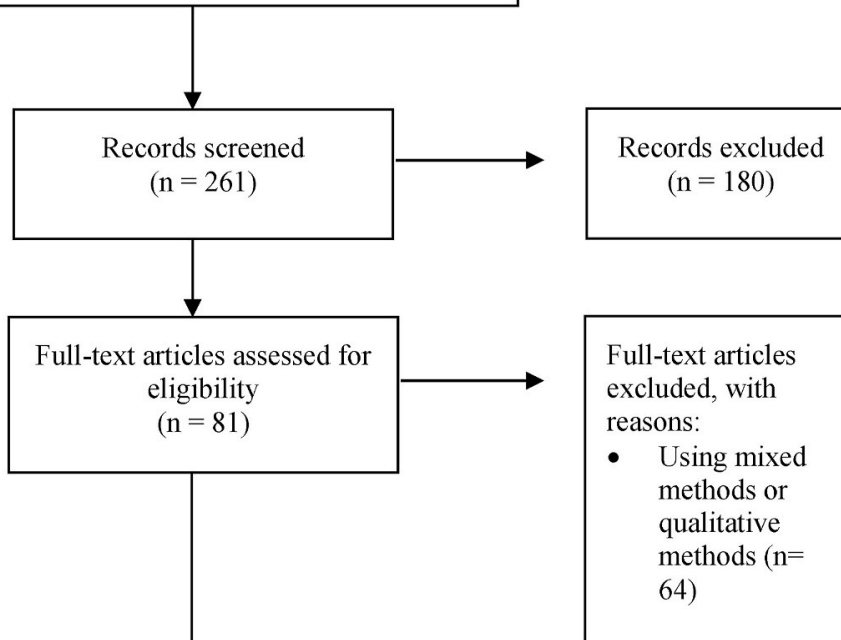

Studies included in qualitative synthesis $(\mathrm{n}=17)$

Fig. 3. Flowchart of the article search. 
The domain of intervention: The key features of PDIs

In this section, we present the findings related to our first research question, namely the features used to guide the designs of the data use PDIs. Overall, the findings suggest that comprehensive data use PDIs incorporated some or all of the key features of effective $\mathrm{PD}$, including content focus, active learning, duration, collective participation, coherence, and ownership.

\section{Content focus}

This review shows that teachers were provided with the PDI contents to develop a variety of knowledge and skills necessary for the process of data use and teacher daily classroom practice. The contents were focused on the knowledge and skills needed in every step of the systematic processes, such as the four Data-Based Decision Making (DBDM) components, found in six of the reviewed studies. The process of data use entails the steps of evaluating and analysing results, setting specific, measurable, attainable, relevant and timely (SMART) goals, determining strategies for goal accomplishment, and finally executing strategies for goal accomplishment (Staman et al., 2017). Other contents encompassed subject matter knowledge, pedagogical content knowledge (PCK), curriculum and assessment, standards, data information systems, etc. (e.g., van der Scheer, Glas, \& Visscher, 2017; van der Scheer \& Visscher, 2016; van der Scheer \& Visscher, 2018).

\section{Active learning}

Another feature incorporated in the data use PDIs is active learning and the results are presented in terms of learning experiences, facilitation of learning, technological support and aids, and structured intervention, activities and routine.

\section{A variety of active learning experiences}

Multiple forms of active learning experiences were incorporated in the data use PDIs (e.g., van der Scheer et al., 2017; van der Scheer \& Visscher, 2016; van der Scheer \& Visscher, 2018). With different data use processes applied, teachers learned and practised using data based on a problem in student learning from their classroom practice and context (Ebbeler, Poortman, Schildkamp, \& Pieters, 2017), critically analysed classroom data and reflected on their professional behaviour (van der Scheer \& Visscher, 2016), developed an instructional plan (van der Scheer \& Visscher, 2018), and directly applied their newly gained skills in their schools (van Geel, Keuning, Visscher, \& Fox, 2017).

\section{Facilitation of teacher learning}

The role of coaches and mentors was salient in many studies to facilitate data teams during and after the PDIs (Kippers, Poortman, Schildkamp, \& Visscher, 2018; Poortman \& Schildkamp, 2016; Reeves \& Chiang, 2018; van der Scheer \& Visscher, 2018). Two facilitators, for example, helped and scaffolded participants during discussions particularly by giving pedagogical scaffolds (Reeves \& Chiang, 2018). Although this study reported a short time PDI, it did address a data use intervention for teachers with pedagogical scaffolding support. In another study, all data teams were supported by an experienced data coach (expert) from a university, who visited them every three weeks for a meeting to work on the steps of the data use intervention (Kippers et al., 2018) and monitored the process of the team and provided the team with just-in-time support in going through the data team cycle (Poortman \& Schildkamp, 2016).

Teacher development was also established through collaborative learning, for instance through collaborative discussion (Reeves \& Chiang, 2018) and collaboration in data teams between colleagues, such as school leaders and a data expert from the same school (Kippers et al., 2018), teacher collaboration in professional learning communities (PLCs) (Ebbeler et al., 2017; Supovitz \& Sirinides, 2017) or networked communities (Lai et al., 2009; McNaughton et al., 2012). Collaboration also took place in the format of data teams through PLCs, consisting of four to six teachers, one to two school leaders (e.g., team leaders), and a quality care manager. Therefore, they could learn from each other, share and exchange ideas in reflective dialogues and share goals or problems among team members to analyse and use data collaboratively to solve a specific educational problem at their schools (Lai et al., 2009; McNaughton et al., 2012; Poortman \& Schildkamp, 2016).

\section{Technological support and aids}

In the reviewed studies, technological tools or aids were used to support data teams. Student Monitoring System (SMS) as data sources were used especially in studies conducted in the Netherlands (e.g., van der Scheer \& Visscher, 2016; van Geel et al., 2017). LMS (Reeves \& Chiang, 2018) and technology-supported interim assessment (mCLASS and CTB/McGraw-Hill's Acuity) (Konstantopoulos, Miller, \& Ploeg, 2013) were other examples of technology support in data use. Moreover, support was also given in terms of protocols, documents and planning aids to help teachers incorporate data use in their schools and practice (van Geel et al., 2016), an eighty-seven-page guiding manual, including worksheets (Kippers et al., 2018), or an extensive set of guidelines and a data analysis course (Poortman \& Schildkamp, 2016).

\section{Structured intervention, activities, and routine}

Almost all data use PDIs to develop teachers' data literacy were organised in structured programmes. These PDIs were structured in terms of the intervention itself, activities, and routines. For instance, highly structured interventions engaged participants in asking and answering four different kinds of questions (e.g., achievement status and growth, strengths and weaknesses) at five different 
student levels (e.g., individual, subgroup, school) with external, standardised assessment data presented in tables, charts, and score reports (Reeves \& Chiang, 2018). During the PDIs, data teams were also provided with structured and guided activities to practise all systematic steps of DBDM (Poortman \& Schildkamp, 2016) and to make all the data use steps as concrete and explicit as possible (Ebbeler et al., 2017). In addition, providing structured routines also gave data teams meaningful learning opportunities (Supovitz \& Sirinides, 2017).

\section{Duration}

The majority of the studies reported that the data use PDIs were intensively conducted in longer periods. Seven studies incorporated one school year data use PDI (Carlson et al., 2011; Kippers et al., 2018; Konstantopoulos et al., 2013; Supovitz \& Sirinides, 2017; van der Scheer et al., 2017; van der Scheer \& Visscher, 2018; van Kuijk, Deunk, Bosker, \& Ritzema, 2016). Only one study reported that the PDI was done during one and a half years (Ebbeler et al., 2017). Five other studies had two-year data use interventions (Poortman \& Schildkamp, 2016; Staman et al., 2017; van der Scheer \& Visscher, 2016; van Geel et al., 2016, 2017). A three-year intervention was implemented in two studies (Lai et al., 2009; McNaughton et al., 2012). The study by Slavin, Cheung, Holmes, Madden, and Chamberlain (2013) reported a four-year data use intervention provided by CDDRE. The shortest duration, a five-day online data literacy intervention, was shown in the study of Reeves and Chiang (2018).

\section{Collective participation}

Collective participation in data use refers to collaboration among different people, for example in data teams, which was evident in all studies with one or more years of data use PDIs (e.g., Ebbeler et al., 2017; Kippers et al., 2018; Staman et al., 2017; van der Scheer et al., 2017; van der Scheer \& Visscher, 2016; van der Scheer \& Visscher, 2018; van Geel et al., 2016; van Geel et al., 2017). This collective participation was done by involving the entire school team to participate in the intervention at class, school, and board levels (van Geel et al., 2017). In some cases, the collaborative intervention included a principal and a support coordinator who facilitated teacher change by providing teachers with organisational and emotional support (van Kuijk et al., 2016).

\section{Coherence}

We found that the data use interventions were coherent. For example, coherence was established by aligning the data use PDIs with national policies, and this was made to ensure teachers' motivation to work on this professional development trajectory (van der Scheer et al., 2017; van der Scheer \& Visscher, 2018). In another study, it was also done by connecting the intervention to the school policy (van der Scheer \& Visscher, 2016).

\section{Ownership}

We found only one study that explicitly stated the incorporation of ownership as one feature of the PDI designs. The study by Ebbeler et al. (2017) indicates that ownership was established by employing collaboration through data teams who worked on urgent educational problems in their own school contexts. Teachers were given the opportunity to choose the problems that they wanted to solve through the data use processes. Other studies, however, reported that the data use processes were embedded in teacher classroom practice where they applied data use to cope with their instructional problems.

\section{The domain of practice: The process of data use}

The results for our research question two concerning the practice of data use processes for instructional improvement show several models that follow systematic (iterative) data use processes for instructional improvement, such as the Four DBDM component model (Staman et al., 2017; van der Scheer et al., 2017; van der Scheer \& Visscher, 2016, 2018; van Geel et al., 2016, 2017), the Data Literacy for Teaching (DLfT) (Reeves \& Chiang, 2018), the Multi-component Model (van Kuijk et al., 2016), and the Eight steps of DBDM (Ebbeler et al., 2017; Kippers et al., 2018; Poortman \& Schildkamp, 2016). Although these models have different required steps, they follow the inquiry (interpretative) processes of using data to improve student outcomes.

\section{Establishing goals}

Of the studies that reported the goal-setting in the data use process, the majority indicated the need for defining problems based on student performance data derived from standardised tests (e.g., Konstantopoulos et al., 2013; van der Scheer \& Visscher, 2018). In the studies by McNaughton, Lai, and Hsiao (2012) and van der Scheer and Visscher (2018), for instance, the data were analysed to examine the gaps between the student achievement and national patterns or achievement standards. However, the data are not sufficient to define student learning problems, therefore, additional data, such as classroom observation data are needed so that they could give better insights to the problems (Lai et al., 2014; McNaughton, Lai, \& Hsiao, 2012; Supovitz \& Sirinides, 2017). These data thus complemented assessment data. The examination of students' strengths and weaknesses and of current instruction helped understand student learning and teaching needs (Lai et al., 2014), and further enabled teachers to define the possible causes of the problem (Ebbeler et al., 2017; Kippers et al., 2018). In this case, some studies showed that data from the literature (theories) were necessary to 
explain the nature of the problem (Carlson et al., 2011; Lai et al., 2014).

\section{Collecting data}

Various types of data were collected during this step, including standardised assessments, attendance, curriculum-based tests, classroom observations, and diagnostic conversations (McNaughton, Lai, \& Hsiao, 2012; Slavinet al., 2013; van der Scheer \& Visscher, 2018; van Geel et al., 2017). Kippers et al. (2018) showed that teachers collected multiple types of quantitative and qualitative data to ascertain the problem scope and to establish goals, to test hypotheses related to the cause of the problem or to seek answers questions, and to evaluate if the goals have been achieved. Since quality is important, teachers also checked the quality of the collected data before they analysed them (Ebbeler et al., 2017). To avoid differences or disagreement among teachers, Lai and McNaughton (2016), for instance, used an evaluation framework for resolving such differences of multiple possible hypotheses and solutions raised by the teachers.

\section{Data sense-making}

The reviewed studies indicated that data sense-making is a crucial part of the data use process in which teachers interpreted data and drew conclusions. Teachers were engaged with transforming data into information by reading and interpreting tables or graphs (Kippers et al., 2018; van der Scheer et al., 2017; van Kuijk et al., 2016) or comparing between students' current performance data and standards (van der Scheer \& Visscher, 2018), thus achieving conclusions about the nature of the problem, answers to the initial questions, or the instructional action that would be taken (Ebbeler et al., 2017; Kippers et al., 2018).

\section{Taking action}

In this step, studies reported a variety of actions that data teams took as the results from the previous data use steps. One study suggested the need for joint solutions involving other relevant stakeholders, such as school leaders to address the issues (Lai \& McNaughton, 2016). Moreover, some studies revealed that instructional actions were formulated in instructional plans containing performance goals for a group of students or for all students and instructional strategies to accomplish such goals (van der Scheer \& Visscher, 2018; van Geel et al., 2017; van Kuijk et al., 2016). Furthermore, van der Scheer and Visscher (2018) pointed out that it was necessary for teachers to evaluate and discuss their plans with their colleagues. Despite the fact that a number of studies suggest implementing instructional plans, teachers' decisions could also lead to using or integrating instructional technology (Kippers et al., 2018). Overall, the studies indicate that it is necessary to involve relevant stakeholders to formulate actions in order to cope with the identified problems through, for example, designing instructional plans or other evidence-based solutions.

\section{Evaluating}

In the final phase of the data use process, evaluation is conducted to measure if the goal has been achieved or the action has been effective in solving the identified problem. Although many studies did not sufficiently give detailed information about this step because it is integrated into the first step, such as the four DBDM component model, in some studies it was evident that evaluation required new data collection, data check and analysis on relevant data, such as data about the implementations of the instructional plans in classrooms and student learning outcomes (Ebbeler et al., 2017; Kippers et al., 2018; van der Scheer \& Visscher, 2018). As the majority of the studies suggested, the result from this last step informed teachers whether they could work on a new problem or had to go back to the previous steps if the identified problem was not solved. This indicates that the process of data use is interactive and cyclical rather than linear.

\section{The domain of impact: PDI effects}

The results of the research question three about the effects of the data use PDIs on teacher and student outcomes are presented below. In general, more than half of the studies investigated the effects of the PDIs on students' outcomes, whereas the others focussed on teacher outcomes and one study on instructional changes.

\section{Teacher outcomes}

The salient effects of the data use PDIs on teacher outcomes can be seen in terms of teacher personal (satisfaction, and, attitudes and beliefs) and professional outcomes (data literacy). Data literacy is the most studied impact of the reviewed studies. Overall, the findings indicate that the data use PDIs positively affected teacher outcomes, particularly satisfaction, attitudes and beliefs, and data literacy.

\section{Teacher satisfaction (personal)}

There is only one study investigating the effects of PDI on teacher reactions to the data use PDI. Ebbeler et al. (2017) sought to find out the extent to which educators were satisfied with the data use intervention and the extent to which educators' attitudes improved after participating in the data use intervention. They found that data team participants felt 'satisfied' to 'very satisfied' with the coaching support by an external data coach provided during the intervention, and with the intervention materials. However, they felt 
rather neutral to satisfied with completing the steps of the data use processes and the experiences with the data team meetings.

\section{Attitude and belief (personal)}

Other studies investigated data use PDI effects on teachers' attitudes and beliefs. The majority of the studies indicated positive effects on teacher attitudes and beliefs. Concerning attitudes and beliefs, Supovitz and Sirinides (2017) showed that the study intervention did not significantly change teachers' perceptions about the importance of instructional data or the importance of student test data or teachers' perceived proficiency using data on either teaching or assessment. However, Ebbeler et al. (2017) concluded that mean scores for attitude increased more for teachers in data team schools than for teachers in the comparison group schools. Reeves and Chiang (2018) also reported that teacher perceptions were also positive. Still, another study indicated large changes in in-service teachers' data use self-efficacy and anxiety (Reeves \& Chiang, 2018). Finally, van der Scheer and Visscher (2016) obtained significant strong intervention effects on teachers' efficacy for instructional strategies and student engagement in both treatment groups, but no significant effects were found for teacher efficacy regarding classroom management. It is also reported that improved teacher efficacy in the first treatment group persisted throughout the second school year. In other words, teachers who were exposed to the intervention had a significantly higher sense of efficacy after the intervention.

\section{Data literacy (professional)}

Effects of data use PDIs on teacher knowledge and skills (data literacy) can be found in several studies. van Geel et al. (2017) reported significant improvements in educators' data literacy after participation in the data use PDIs. Another study showed that teachers significantly improved their data-related skills although they had different initial basic teaching skills (van der Scheer et al., 2017). Ebbeler et al. (2017) found that teacher data literacy skills improved more for teachers in data team schools with a medium to a large effect size of $\mathrm{d}=0.71$.

\section{Instructional change}

Only one study reported the PDI effect on instructional quality. Supovitz and Sirinides (2017) found moderate and significant effects on expert judgments of the quality of instruction caused by the intervention. There was also a statistically significant difference in the academic rigour (design and enactment) of the lessons from the treatment teachers in comparison to control teachers, with a standardised effect size of 0.43 .

\section{Student outcome (subject-related outcome)}

The studies evaluating the impacts of data use PDIs with experimental and quasi-experimental methods focused largely on student achievement and the findings showed different results. Some studies reported significant effects of the PDIs on student achievement while others did not.

Significant effects of the PDIs on student achievement were reported in a number of studies. In New Zealand, Lai et al. (2009) concluded that intervention through collaboration resulted in increased rates of achievement that were variable but sustained across three years. Over three years it showed an average achievement gain across cohorts followed longitudinally by one year's progress in addition to expected progress over that period with effect sizes of $d=0.62$. Similarly, significant accelerations were seen in achievement for the total group of students who were tracked longitudinally (McNaughton et al., 2012). The CDDRE intervention proved statistically significant, resulting in districtwide improvements in student mathematics achievement (Carlson et al., 2011).

Other studies reported small to medium effect sizes, mixed findings, and the absence of main effects. Supovitz and Sirinides (2017) found small and marginally significant impacts on student performance. van Kuijk et al. (2016) also obtained an effect size of $d=0.37$ indicating a small to medium effect. Another finding showed directionally positive effects on reading and math measures and effect sizes generally increased in the third and fourth year of intervention (Slavin et al., 2013). In a study by van Geel et al. (2016), the findings indicate that data use can improve student achievement, although effects differ across schools. Interaction effects suggest that data use is especially effective for schools with a large proportion of low socioeconomic economic status (SES) students. The interaction effect was positive and significant for low SES, but this was also the case for high SES students. Combining the interaction effects of the intervention and student SES and school SES leads to the conclusion that the effect of intervention had a positive effect for both low and high SES students, regardless of their school's SES, and only led to a negative effect on student achievement for medium SES students in high SES schools. Moreover, another study showed that the treatment effect was positive but not consistently significant across all grades. The treatment effect was smaller in lower grades (i.e., kindergarten to second grade) and larger in upper grades (i.e., third grade to eighth grade). Significant treatment effects were observed in Grade 3-8 analyses in mathematics (Konstantopoulos et al., 2013).

Moreover, Poortman and Schildkamp (2016) reported mixed findings. Out of nine data teams, four were not able to solve their problem and four were able to improve student achievement significantly. van der Scheer and Visscher (2018) confirmed the finding that no intervention effect was found on mathematical achievement across all students, but the students in the extended instruction group benefited considerably from the data use intervention. Extended instruction group students in the experimental group scored on average 2.41 ability score points higher than those in the control group.

Lastly, with the Focus Intervention, Staman et al. (2017) reported that schools exposed to the intervention did not benefit much from it in terms of their students' performance in mathematics. No main intervention effects were also found; in all cases, effect sizes for the main effects were small. Nevertheless, three analyses resulted in statistically significant interaction effects. The effects were 
more positive for students with lower pre-test scores and with a lower socioeconomic status.

\section{Discussion}

This systematic literature review contributes to the existing literature by evaluating the components of the PD pathways in the context of data use PDIs. Considering the significance of the underlying processes of data use in understanding its pathways (Coburn \& Turner, 2011), the practice of data use was included in our proposed framework that was developed based on the general PD pathways by Desimone (2009) and Merchie et al. (2016). This framework further served as a basis for this review. The present study provides evidence on the effects of data use PDIs on teacher and student outcomes by evaluating the key features of data use PDIs, the practices of data use processes, and eventually their impacts. In general, the findings highlight the importance of incorporating some or all key features of PDIs. The process of data use is regarded not only as an improvement strategy with a three-part interrelated and cyclical process of intentionally using data to inform instruction but also as a constructivist learning process. Finally, the data use PDIs have promising results on teacher satisfaction, attitudes and beliefs, as well as student subject related outcomes. However, the findings also show that the effects on student outcomes are not straightforward but mediated by teacher outcomes, practices of data use and instructional changes. Overall, despite those findings, there is no evidence in the studies that PD features, teacher outcomes, practices of data use and instructional changes were, respectively, evaluated to support claims on their effects on student outcomes.

\section{Key features}

This review indicated the importance of incorporating the key features in the designs of data use PDIs. The PDI contents focused on developing teachers' knowledge and skills both in the process of data use and effective teaching (Shulman, 1986, 1987). These contents are fundamental for data literacy (Mandinach \& Gummer, 2016). The integration of both knowledge domains offers teachers not only knowledge and skills of systematic data use processes to the maximum extent, while at the same time, developing them with pedagogical content knowledge to enable them to improve instructional practices and student outcomes.

The studies reporting active learning also highlighted the significant roles of coaches in facilitating teacher learning through various types of learning activities supported by technology. This is in line with previous research that there is a positive relationship between coaching, the implementation of data use and student achievement (Lockwood, Sloan McCombs, \& Marsh, 2010). Since technology becomes an important component in data use (e.g., Coburn \& Turner, 2011; Mandinach, 2012), the role of technology is evident during the steps of goal setting, data collection and data sense-making, but we found insufficient evidence on how technology is integrated during the subsequent steps, for example how teachers integrate relevant technology to support instructional practices in classrooms.

As evident in this study, coherence was established by aligning the PDIs with school or national policies or standards. In this way, the PDIs are regarded as being externally consistent as they meet the expectation of policymakers and stakeholders. However, we did not find any evidence that coherence was ensured by linking it to external accountability demands since such demands can cause

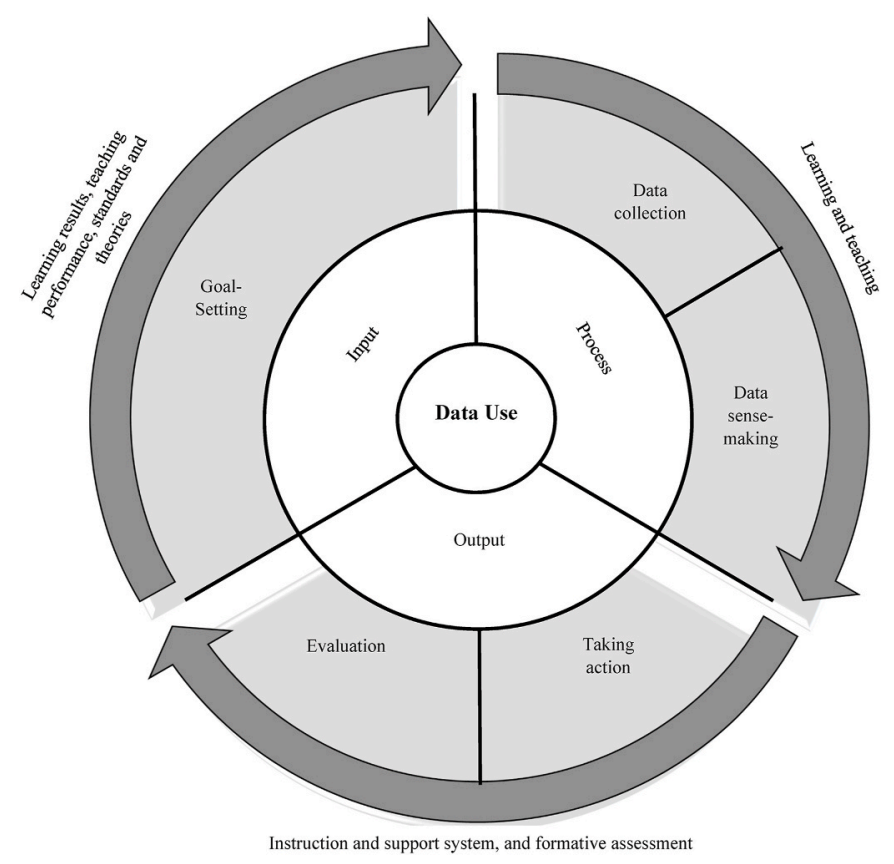

Fig. 4. The interrelated and cyclical inquiry processes of data use. 
teachers' psychological pressures during learning (Datnow \& Hubbard, 2016).

Considering the complexity of data use in which teachers need to master a variety of knowledge and skills (Mandinach \& Gummer, 2016) and develop positive attitudes and beliefs in data use (Datnow \& Hubbard, 2016), it is found that all of the PDIs but one lasted between one to four years. This sustained duration is considered more effective for teacher learning (Houtveen \& van de Grift, 2012; Jimerson et al., 2019). In this study, it has been found that longer PDIs contribute to both teacher and student learning, but programmes with shorter durations do not seem to have an impact on student achievement. Therefore, it is suggested that teachers should be provided with sustained, on-going data use PD rather than with the traditional model of one-shot PD (Hamilton et al., 2009; Means, Padilla, \& Gallagher, 2010). Although the duration is crucial for effective PDIs, it is also necessary to consider their efficiency. van der Scheer and Visscher (2018) reported that approximately US\$2500 was spent per teacher for a one-year intervention, thus suggesting to train one or a few teachers intensively, who can then coach their colleagues, and to make data use part of the teacher training curriculum.

Last, involving relevant stakeholders and teachers working on their instructional problems can develop commitment or ownership of data use that further contributes to the sustainability of the innovation. Ownership here is both an outcome and a precondition, which is necessary for effective collective participation in data use. This collaboration among stakeholders is also required for the understanding that data use to improve instruction is a complex, multi-faceted activity in which teachers need to work in collaborative inquiry about their practice (Schnellert, Butler, \& Higginson, 2008).

\section{Inquiry processes of data use}

Concerning the process of data use, this study further revealed two important findings. First, the models of data use processes have shed light on the instructional improvement strategy to intentionally use data to improve instruction and student learning (Fig. 4). The processes were interrelated and cyclical where data teams sometimes went back and forth during the processes. The processes started by goal-setting as the input for further processes since it drove data collection and sense-making as the main processes of intentionally using data to improve instruction and student learning. The processes of taking action and evaluation served as the output of data use, and the results further informed the input and so on.

SMART goals are important in data use (Hamilton et al., 2009; Schildkamp, 2019). This study found that these goals are developed primarily on the results of analysis and the evaluation of student learning results, teaching and learning performance, curriculum, standards and theories. Student learning results as the end product of instruction are not sufficient to define the nature of the learning problems; therefore, they must be matched with the data of how students learn and how teachers perform in their classrooms. Looking at these two sides helps to better frame the problems to address when developing SMART goals. Although student involvement in data use has not been systematically studied (Hoogland et al., 2016), this study showed the role of student learning processes in shaping the data use goals in addition to the other types of data. Data teams found curriculum, standards and theories useful data to identify gaps between the attained and expected student results as well as informative for possible solutions to the problems. In conclusion, data teams collect various types of data and triangulate them to set up SMART goals that they want to achieve through data use processes.

During data collection and sense-making, teachers in data teams are collaboratively involved in collecting, interpreting, and drawing conclusions about student learning, teaching performance, etc. Teachers did these activities to develop goals and evaluate their evidence-based actions for a data analysis guide or evaluation framework, for example, became essential tools. We found that these tools could help teachers do the activities and that in cases of disagreement that may appear due to teacher different opinions or ideas, they were useful in tackling such differences.

Finally, classroom instruction and its support system, as well as a formative and summative assessment, provided evidence of taking action and evaluation in data use. Data teams collaboratively developed instructional plans. The plans needed to be well designed and meet the stakeholders' expectations so that the actions taken met quality criteria in terms of internal and external consistencies. The instructional actions were evaluated either by employing formative or summative assessment and these assessment data were analysed to improve the instructional actions and to determine if the goals were achieved. However, it was evident that the evaluation step was either the last step of the data use processes if the goals were achieved or the tipping point for the processes when the goals were not met. This then made data use as an interrelated and cyclical process of data use.

In general, the study findings about the process of data use confirm previous findings (e.g., Lai \& Schildkamp, 2013; Mandinach \& Gummer, 2016; Marsh, 2012; Schildkamp \& Poortman, 2015). However, this study revealed two approaches to a cyclical process of data use: a goal (input)-based approach and an evaluation (output)-based approach. In a goal-based approach, data teams start with the process of data use intending to achieve and then continue to data collection and sense-making, and finally taking action, while in the evaluation-based approach they begin with evaluation step and move to the goal-setting and the subsequent steps. Additionally, the study has shed lights on the importance of both student and teacher performance data. Student data do not only include assessment results but also the ways how students learn. Teacher performance involves data about instructional content and pedagogical strategies. Matching these two types of data could see the gaps and triangulating them helps define instructional conditions.

The second important finding is related to teacher learning. The process of data use serves not only as a data-informed improvement strategy, but as a constructivist learning process as well. Teacher learning in data use is not conceived of as mastering pre-determined contents (e.g., data analysis, pedagogical content knowledge), but it is regarded as constructing new knowledge through engaging in each process of data use and its meaningful, authentic learning activities and participating in collaborative interactions. Since each data use process requires particular knowledge and skills (e.g., Mandinach \& Gummer, 2016), teachers' knowledge and skills were developed sequentially based on each data use process requirements. 


\section{PDI impacts}

The study findings indicate that most of the reviewed studies investigated the effects of PDIs on teacher and student outcomes, but only one study focused on instructional changes. A teacher professional outcome (data literacy) was mainly the target of data use PDIs and was predominantly measured by data use knowledge tests. Although such tests could measure teachers' cognitive goals of data use, they may not assess teachers' actual capability of applying systematic data use. Therefore, using other measurement instruments that are appropriate with outcomes to be measured, such as classroom observations, teachers' logs, etc. (see Merchie et al., 2016) could capture a full view of teachers' data literacy.

Assessing data literacy has raised challenges in what data literacy entails in different contexts and in instruments to measure the impacts. Although Mandinach and Gummer (2016) provided a general construct of data literacy for teaching, there has been no agreement among scholars on what it entails in different contexts. Data literacy might be defined differently in the context of teaching English where English plays both as message and medium or teaching English through English. Additionally, there is no one-size-fits-all instrument that can measure various impacts of data use PDIs. Some instruments are simple and easy to use but they only measure lower levels of performance, while others can better evaluate higher performance levels but they are not feasible. For instance, when assessing teacher data-related performance, observation is a good strategy but it might not be feasible to collect and analyse data from a large number of teachers due to several restrictions. According to Borg (2018), "decisions about how to evaluate PDI impacts are shaped not only by theoretical considerations but also (and often more powerfully) by practical constraints such as the availability of time, funding and expertise" (p, 211).

Moreover, it is argued that data literacy as a teacher professional outcome plays a significant role in using data for instructional improvement. Although data literacy alone is not sufficient to support teachers in the implementation and sustainability of the data use practice, it also requires personal development, such as teacher satisfaction, beliefs and attitudes towards data use. Datnow and Hubbard (2016) suggested that capacity building should directly address teacher beliefs and data literacy to be effective.

In the era of evidence-based education, the use of data has gradually been required in teaching profession to improve teaching and learning. In this regard, data literacy becomes an important key to such demand. Teachers can collect data to determine student needs, to determine aspects of teaching that contribute to student learning, and to help them develop beliefs and knowledge that support effective teaching (Wieman, 2014). In other words, teachers may use student test results combined with other data to adapt instruction to address student learning needs while at the same time to develop their teaching efficacy. These dual purposes will help shape effective teaching.

Furthermore, as it is found in this study only one study explicitly looked at the impact of data use interventions on the quality of instruction. The existing studies merely focused on the effects of data use PDIs and data use practices directly on either teacher or student outcomes, but little attempt was made to find out the impacts on instructional conditions. We argue that looking at this mediating variable to the impacts on student outcomes would clarify the PD pathways from the interventions to the impacts, particularly on student outcomes.

With regard to the impacts on student outcomes, the studies focused only on subject related outcomes, particularly on student cognitive outcomes. It is evident that the data use PDI effects on student outcomes are not univocal. It cannot be assumed that some of the PDIs are more or less unsuccessful because the impacts of the interventions can be seen after several years.

The effectiveness of PDIs on student outcome depends on many factors, including time. During PDIs teachers need to learn and practise a complex set of data literacy and after the completion of the PDIs, they might still require more time to implement data use in their instruction. Consequently, the effects on student outcomes could not be seen right after the interventions. As it is evident in one study that the impacts of the study intervention were not found in the first half-year but after one school year (van der Scheer \& Visscher, 2018). This indicates the importance of duration in data use PDIs and sufficient time to allow for a realistic assessment of student outcomes.

Overall, even though the findings suggest that the data use PDIs could potentially improve teacher outcomes and student subject related outcomes, we did not find evidence in the studies that PD features, teacher outcomes, practices of data use and instructional changes were, respectively, evaluated to support claims on their effects on student outcomes. Therefore, a question may arise whether or not improved student outcomes were caused by the interventions when there is missing evidence on the effectiveness of each PD pathway component.

\section{Limitation}

There are some limitations to this study. First, it only reviewed studies that used experimental and quasi-experimental methods and focussed on the effectiveness of data use PDIs. So, the results might not cover a complete understanding of the data use PD pathways and its components. Therefore, there is a call for further research to investigate such PD pathways by studying the interventions, the practices of data use and eventually the outcomes of studies that employ different approaches and methods, and that focus on not only the effectiveness but also on the efficiency of data use PDIs.

Second, the majority of the selected studies was conducted in the Netherlands. This could be due to the fact that the national policy in the Netherlands has targeted at least $90 \%$ of primary and secondary education schools to use data in a systematic manner by 2018 (Gelderblom et al., 2016, p. 5). This study did not give a global insight into data use PDIs, and thus future studies could address the issue by including and synthesising studies with a variety of methods from countries around the globe. 


\section{Conclusion}

The main goal of this review was to investigate the evidence on the effects of data use PDIs on teacher and student outcomes. More specifically, this review contributes to the existing literature by presenting the linkages of the key features of data use PDIs, the practices of data use, and their effects on teacher and student outcomes.

Since data use has gained much attention due to its potential impacts on student outcomes, professional development interventions (PDIs) were developed and studied to investigate their impacts on teacher and student outcomes. This study revealed the importance of incorporating effective PD features, using a systematic inquiry process of data use as an improvement strategy and a constructivist learning process. The results also uncovered the effects of data use PDIs on teacher satisfaction, data literacy, attitudes and beliefs, as well as student subject related outcomes.

Based on the findings of this study, Fig. 5 is a description of how data use PDIs that could have indirect impacts on student outcomes are mediated by the practices of data use, teacher outcomes and improved learning conditions.

As illustrated in Fig. 5, data use PDIs interact with the contexts to shape the practices of data use and consequently results in the impacts. First, the domain of intervention (input) shows the importance of incorporating the key features of PD into data use PDIs with the intention of developing teachers' systematic use of data in their daily instruction and to improve student outcomes. Second, participation in the PDIs contributes to teacher outcomes (output), such as personal outcomes (e.g., increased levels of satisfaction, attitudes and beliefs) and professional outcomes (e.g., data literacy).

Third, by having such qualities teachers apply their newly gained knowledge and skills by intentionally using data to inform instruction in their daily classrooms through interactive and cyclical processes. The processes begin with goal-setting in which they set goals by analysing and evaluating student achievement results and link them to attainment standards and existing theories. The developed goal further guides data collection and sense-making as the main processes of intentionally using data to improve instruction and student learning. During these processes, teachers collect, interpret, and draw conclusions about the primary data of their student learning and teaching practice. The processes of taking action and evaluation indicate the output part of data use processes in which teachers, for instance, design and implement data-informed instruction, and then formatively evaluate if it results in the desired outcome stated in the goal. The evaluation result will determine the necessary actions, for instance, whether they could go back to the input part or process part.

The ways in which teachers use data are shaped by contextual factors related to individual teachers' and data teams' data literacy, attitudes and beliefs, etc. (user and team characteristics), school support, facilitation, etc. (school characteristics), and accountability demands, standards, etc. (policy characteristics). Here, the contextual factors serve as crucial mediators and moderators to data use (the domain of practice (process)).

Finally, the practice of such data use contributes consecutively to improved conditions of learning in the classroom, such as lesson design and enactment (the domain of impact (output)) and student subject related outcomes (the domain of impacts (output)).

Furthermore, Mandinach and Gummer (2016) argued that the impacts of PDIs on student outcomes are complex and multi-faceted and they are achieved through teacher development and improved instructional conditions. So, if the goal is to find out the effects of data use PDIs on student outcomes, then the variables of teacher outcomes, the practice of data use and instructional condition really

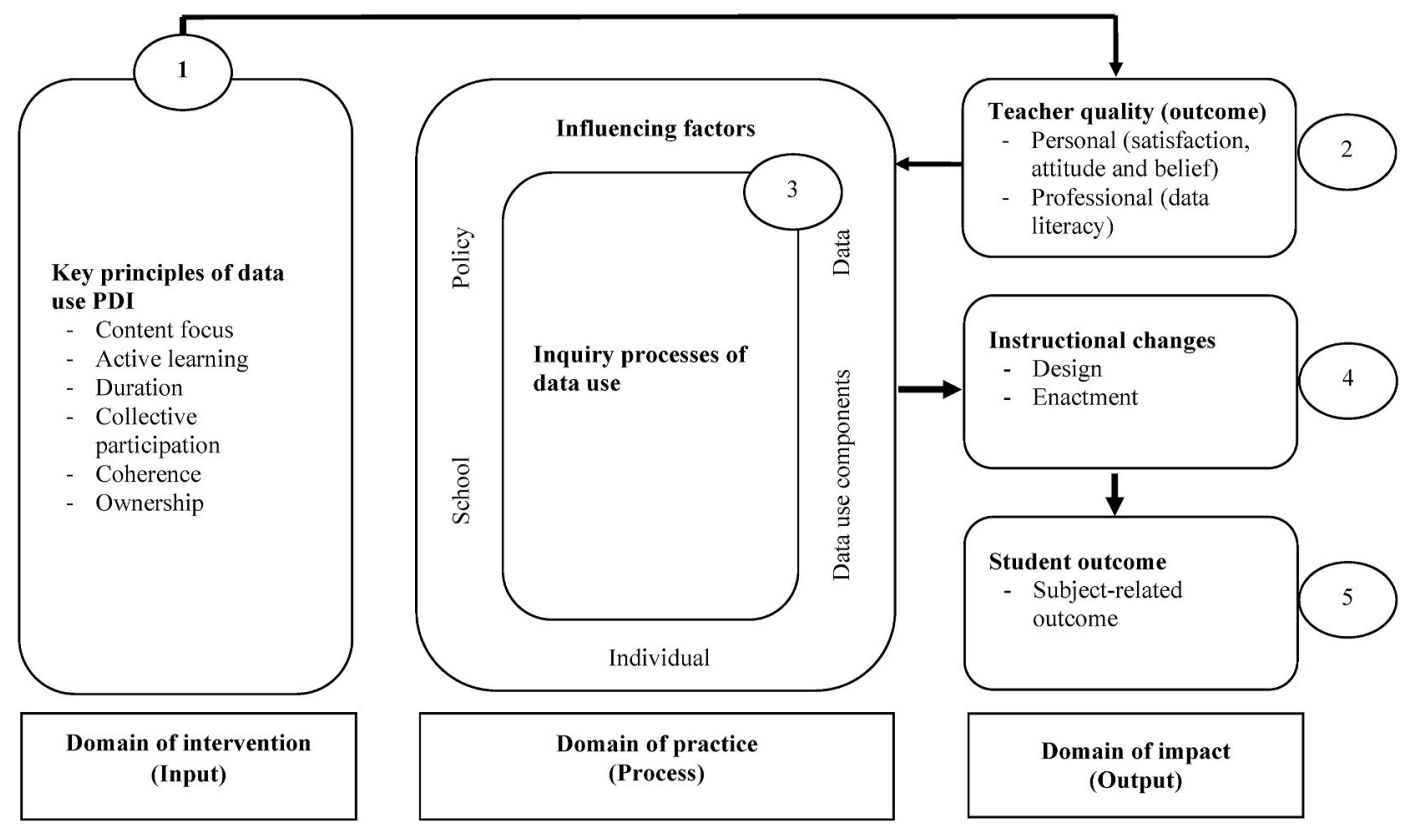

Fig. 5. Description of pathways from data use PDIs to teacher and student outcomes. 
matter. Therefore, it is necessary to first evaluate the incorporation of the key PD features before, during and after the intervention and then teacher outcomes (Merchie et al., 2016). In this case, teacher outcomes should be assessed before and after teacher participation in a data use PDI to see the improvement. Another important component is to evaluate the practice of data use that teachers follow by using observation, for instance. Since such practice is complex and shaped by various factors (e.g., Coburn \& Turner, 2011; Mandinach, 2012; Schildkamp \& Poortman, 2015), it is necessary to find out if teachers really use data to inform their instruction. It is possible that teachers have learned data use from a PDI, but do not apply it due to lack of collaboration, support, etc. Moreover, it is also crucial to see if instructional condition is improved as a result of data use practice. In so doing, instructional conditions can be assessed by, for example structured observation with which a teacher's class is observed before, during, and after the PDI. Only after evaluating those mediating variables can the link between the PDI and student outcomes be clearly determined.

\section{Implications for practice and research}

Several implications for practice and future research should be noted in relation to the present study. For practice, professional development interventions (PDI) require principled designs, implementation and evaluation. In other words, data use PDIs should integrate effective features so that the programmes can better assist teachers in developing data literacy. It is also important that data use PDIs incorporate an inquiry process of data use that guides teachers or data teams to systematically use data to inform instruction, and that provides teachers with meaningful learning experiences. Additionally, evaluating PDIs impacts is crucial as it gives evidence on their (in)effectiveness, and such evidence can be a data source for reflection or for accountability.

For future research, this study contributes to a conceptual framework and a useful lens for understanding data use PDI pathways. Through this lens, the effects of data PDIs on student outcomes can be systematically tracked. Despite this framework and the findings, the study leaves several issues that need to be addressed in further research. For example, since we found no studies targeting teacher cultural outcomes, further studies might investigate the impacts of PDIs on teacher cultural outcomes to give a clear picture of teachers-related outcomes: the issue might include the investigation on what and how data use PDI could influence forms of collaboration or PLCs. Future studies may also investigate the effects of data use PDIs on general education-related outcomes and other learning domain objectives, such as affective (attitudes and dispositions) and psychomotor (skills and behaviour). Another worthy topic of future research includes data use PDI pathways by studying all components of the pathways to determine causal links between PDI and student outcomes or by finding out how or which intervention features contribute to teacher outcomes, practices of data use, instructional changes, and student outcomes respectively. Finally, there is a need for future studies to expand the time frame, using more search terms and databases so that they can enrich our understanding of data use PDI pathways.

\section{Authors' statement}

The authors certify that they have all contributed to all the research actions (e.g. the concept, design, analysis, writing, or revision of the manuscript). Furthermore, the authors also certify that this manuscript or similar material has not been submitted or published elsewhere.

\section{Acknowledgements}

AcknowledgementsThis research was sponsored by the 5000-Doctor Overseas Programme, Ministry of Religious Affairs Republic of Indonesia.

\section{Appendix A. Supplementary data}

Supplementary data to this article can be found online at https://doi.org/10.1016/j.edurev.2020.100362.

\section{References}

Blank, R. K., de las Alas, N., \& Smith, C. (2008). Does teacher professional development have effects on teaching and learning? Evaluation findings from programs in 14 states. Washington: Council of Chief State School Officers.

Borg, S. (2018). Evaluating the impact of professional development. RELC Journal, 49(2), 195-216. https://doi.org/10.1177/0033688218784371

Carlson, D., Borman, G. D., \& Robinson, M. (2011). A multistate district-level cluster randomized trial of the impact of data-driven reform on reading and mathematics achievement. Educational Evaluation and Policy Analysis, 33(3), 378-398. https://doi.org/10.3102/0162373711412765

Coburn, C. E., \& Turner, E. O. (2011). Research on data use: A framework and analysis. Measurement, 9(4), 173-206. https://doi.org/10.1080/ 15366367.2011.626729

Compen, B., Schelfhout, W., \& De Witte, K. (in press, 2020). The impact of teacher engagement in an interactive webinar series on the effectiveness of financial literacy education. British Journal of Educational Technology. https://doi.org/10.1111/bjet.13013

Compen, B., De Witte, K., \& Schelfhout, W. (2019). The role of teacher professional development in financial literacy education: A systematic literature review. Educational Research Review, 26, 16-31. https://doi.org/10.1016/j.edurev.2018.12.001

Darling-Hammond, L., Hyler, M. E., \& Gardner, M. (2017). Effective teacher professional development. Palo Alto, CA: Learning Policy Institute.

Datnow, A., \& Hubbard, L. (2016). Teacher capacity for and beliefs about data-driven decision making: A literature review of international research. Journal of Educational Change, 17(1), 7-28. https://doi.org/10.1007/s10833-015-9264-2 
Desimone, L. (2009). Improving impact studies of teachers' professional development: Toward better conceptualizations and measures. Educational Researcher, 38(3), 181-199. https://doi.org/10.3102/0013189X08331140

Desimone, L., \& Garet, M. S. (2015). Best practices in teachers' professional development in the United States. Psychology, Society, \& Education, 7(3), 252-263. https:// doi.org/10.25115/psye.v7i3.515

Ebbeler, J., Poortman, C. L., Schildkamp, K., \& Pieters, J. M. (2017). The effects of a data use intervention on educators' satisfaction and data literacy. Educational Assessment, Evaluation and Accountability, 29(1), 83-105. https://doi.org/10.1007/s11092-016-9251-z

van Geel, M., Keuning, T., Visscher, A. J., \& Fox, J.-P. (2016). Assessing the effects of a school-wide data-based decision-making intervention on student achievement growth in primary schools. American Educational Research Journal, 53(2), 360-394. https://doi.org/10.3102/0002831216637346

van Geel, M., Keuning, T., Visscher, A., \& Fox, J. P. (2017). Changes in educators' data literacy during a data-based decision making intervention. Teaching and Teacher Education, 64, 187-198. https://doi.org/10.1016/j.tate.2017.02.015

Gelderblom, G., Schildkamp, K., Pieters, J., \& Ehren, M. (2016). Data-based decision making for instructional improvement in primary education. International Journal of Educational Research, 80, 1-14. https://doi.org/10.1016/j.ijer.2016.07.004

Guskey, T. R., \& Yoon, K. S. (2009). What works in professional development? Phi Delta Kappan, 90(7), 495-500. https://doi.org/10.1177/003172170909000709

Hamilton, L., Halverson, R., Jackson, S. S., Mandinach, E., Supovitz, J. A., \& Wayman, J. C. (2009). Using student achievement data to support instructional decision making. National Center for Education Evaluation and Regional Assistance, Institute of Education Sciences, U.S. Department of Education.

Hoogland, I., Schildkamp, K., van der Kleij, F., Heitink, M., Kippers, W., Veldkamp, B., et al. (2016). Prerequisites for data-based decision making in the classroom: Research evidence and practical illustrations. Teaching and Teacher Education, 60, 377-386. https://doi.org/10.1016/j.tate.2016.07.012

Houtveen, T., \& van de Grift, W. J. C. M. (2012). Improving reading achievements of struggling learners. School Effectiveness and School Improvement, 23(1), 71-93. https://doi.org/10.1080/09243453.2011.600534

Ikemoto, G. S., \& Marsh, J. A. (2007). Cutting through the "data-driven" mantra: Different conceptions of data-driven decision making. The Yearbook of the National Society for the Study of Education, 106(1), 105-131. https://doi.org/10.1111/j.1744-7984.2007.00099.x

Jeanpierre, B., Oberhauser, K., \& Freeman, C. (2005). Characteristics of professional development that effect change in secondary science teachers' classroom practices. Journal of Research in Science Teaching, 42(6), 668-690. https://doi.org/10.1002/tea.20069

Jimerson, J. B., Garry, V., Poortman, C. L., \& Schildkamp, K. (2019). Implementing a data use intervention in a United States context: Enabling and constraining factors (2019, April) Paper Presented at the Annual Conference of the. Toronto, Canada: American Educational Research Association.

Johnson, C. C., Kahle, J. B., \& Fargo, J. D. (2007). A study of the effect of sustained, whole-school professional development on student achievement in science. Journal of Research in Science Teaching, 44(6), 775-786. https://doi.org/10.3102/0002831207308221

Kippers, W. B., Poortman, C. L., Schildkamp, K., \& Visscher, A. J. (2018). Data literacy: What do educators learn and struggle with during a data use intervention? Studies In Educational Evaluation, 56, 21-31. https://doi.org/10.1016/j.stueduc.2017.11.001

Konstantopoulos, S., Miller, S. R., \& Ploeg, A.v. d. (2013). The Impact of Indiana's system of interim assessments on Mathematics and Reading achievement. Educational Evaluation and Policy Analysis, 35(4), 481-499. https://doi.org/10.3102/0162373713498930

van Kuijk, M. F., Deunk, M. I., Bosker, R. J., \& Ritzema, E. S. (2016). Goals, data use, and instruction: The effect of a teacher professional development program on reading achievement. School Effectiveness and School Improvement, 27(2), 135-156. https://doi.org/10.1080/09243453.2015.1026268

Lai, M. K., \& McNaughton, S. (2016). The impact of data use professional development on student achievement. Teaching and Teacher Education, 60, 434-443. https:// doi.org/10.1016/j.tate.2016.07.005

Lai, M. K., McNaughton, S., Amituanai-Toloa, M., Turner, R., \& Hsiao, S. (2009). Sustained acceleration of achievement in reading comprehension: The New Zealand experience. Reading Research Quarterly, 44(1), 30-56. https://doi.org/10.1598/RRQ.44.1.2

Lai, M. K., \& Schildkamp, K. (2013). Data-based decision making: An overview. In K. Schildkamp, M. K. Lai, \& L. Earl (Eds.), Data-based decision making in education: Challenges and opportunities (17 ed., pp. 9-21). Dordrecht: Springer.

Lai, M. K., Wilson, A., McNaughton, S., \& Hsiao, S. (2014). Improving achievement in secondary schools: Impact of a literacy project on reading comprehension and secondary school qualifications. Reading Research Quarterly, 49(3), 305-334. https://doi.org/10.1002/rrq.73

Lockwood, J. R., Sloan McCombs, J., \& Marsh, J. A. (2010). Linking reading coaches and student achievement: Evidence from Florida middle schools. Educational Evaluation and Policy Analysis, 32(3), 372-388. https://doi.org/10.3102/0162373710373388

Mandinach, E. B. (2012). A perfect time for data use: Using data-driven decision making to inform practice. Educational Psychologist, 47(2), 71-85. https://doi.org/ $10.1080 / 00461520.2012 .667064$

Mandinach, E. B., \& Gummer, E. S. (2015). Data-driven decision making: Components of the enculturation of data use in education. Teachers College Record, 117(4), $1-12$.

Mandinach, E. B., \& Gummer, E. S. (2016). What does it mean for teachers to be data literate: Laying out the skills, knowledge, and dispositions. Teaching and Teacher Education, 60, 366-376. https://doi.org/10.1016/j.tate.2016.07.011

Marsh, J. A. (2012). Interventions promoting educators' use of data: Research insights and gaps. Teachers College Record, 114(11), 1-48.

McNaughton, S., Lai, M. K., \& Hsiao, S. (2012). Testing the effectiveness of an intervention model based on data use: A replication series across clusters of schools. School Effectiveness and School Improvement, 23(2), 203-228. https://doi.org/10.1080/09243453.2011.652126. *.

Means, B., Padilla, C., \& Gallagher, L. (2010). Use of education data at the local level: From accountability to instructional improvement. Washington, DC: U.S. Department of Education, Office of Planning, Evaluation, and Policy Development. https://files.eric.ed.gov/fulltext/ED511656.pdf.

Merchie, E., Tuytens, M., Devos, G., \& Vanderlinde, R. (2016). Evaluating teachers' professional development initiatives: Towards an extended evaluative framework. Research Papers in Education, 33(2), 143-168. https://doi.org/10.1080/02671522.2016.1271003

Penuel, W. R., Fishman, B. J., Yamaguchi, R., \& Gallagher, L. P. (2007). What makes professional development effective? Strategies that foster curriculum implementation. American Educational Research Journal, 44(4), 921-958. https://doi.org/10.3102/0002831207308221

Petticrew, M., \& Roberts, H. (2006). Systematic reviews in the social sciences: A practical guide. Oxford: Blackwell.

Poortman, C. L., \& Schildkamp, K. (2016). Solving student achievement problems with a data use intervention for teachers. Teaching and Teacher Education, 60, 425-433. https://doi.org/10.1016/j.tate.2016.06.010

Reeves, T. D., \& Chiang, J. L. (2018). Online interventions to promote teacher data-driven decision making: Optimizing design to maximize impact. Studies In Educational Evaluation, 59, 256-269. https://doi.org/10.1016/j.stueduc.2018.09.006

Rogge, N., Agasisti, T., \& De Witte, K. (2017). Big data and the measurement of public organizations' performance and efficiency: The state-of-the-art. Public Policy and Administration, 32(4), 263-281. https://doi.org/10.1177/0952076716687355

van der Scheer, E. A., Glas, C. A. W., \& Visscher, A. J. (2017). Changes in teachers' instructional skills during an intensive data-based decision making intervention. Teaching and Teacher Education, 65, 171-182. https://doi.org/10.1016/j.tate.2017.02.018

van der Scheer, E. A., \& Visscher, A. J. (2016). Effects of an intensive data-based decision making intervention on teacher efficacy. Teaching and Teacher Education, 60, 34-43. https://doi.org/10.1016/j.tate.2016.07.025

van der Scheer, E. A., \& Visscher, A. J. (2018). Effects of a data-based decision-making intervention for teachers on students' mathematical achievement. Journal of Teacher Education, 69(3), 307-320. https://doi.org/10.1177/0022487117704170

Schildkamp, K. (2019). Data-based decision-making for school improvement: Research insights and gaps. Educational Research, 1-17.

Schildkamp, K., \& Kuiper, W. (2010). Data-informed curriculum reform: Which data, what purposes, and promoting and hindering factors. Teaching and Teacher Education, 26(3), 482-496. https://doi.org/10.1016/j.tate.2009.06.007

Schildkamp, K., \& Poortman, C. (2015). Factors influencing the functioning of data teams. Teachers College Record, 117(4), 1-42.

Schildkamp, K., Poortman, C. L., \& Handelzalts, A. (2016). Data teams for school improvement. School Effectiveness and School Improvement, 27(2), 228-254. https:// doi.org/10.1080/09243453.2015.1056192

Schildkamp, K., Poortman, C., Luyten, H., \& Ebbeler, J. (2017). Factors promoting and hindering data-based decision making in schools. School Effectiveness and School Improvement, 28(2), 242-258. https://doi.org/10.1080/09243453.2016.1256901 
Schildkamp, K., Smit, M., \& Blossing, U. (2019). Professional development in the use of data: From data to knowledge in data teams. Scandinavian Journal of Educational Research, 63(3), 393-411. https://doi.org/10.1080/00313831.2017.1376350

Schnellert, L. M., Butler, D. L., \& Higginson, S. K. (2008). Co-constructors of data, co-constructors of meaning: Teacher professional development in an age of accountability. Teaching and Teacher Education, 24(3), 725-750.

Shen, J., \& Cooley, V. E. (2008). Critical issues in using data for decision-making. International Journal of Leadership in Education, 11(3), 319-329. https://doi.org/ $10.1080 / 13603120701721839$

Shulman, L. S. (1986). Those who understand: Knowledge growth in teaching. Educational Researcher, 15(2), 4-14.

Shulman, L. S. (1987). Knowledge and teaching: Foundations of the new reform. Harvard Educational Review, 57(1), 1-22.

Slavin, R., Cheung, A., Holmes, G., Madden, N., \& Chamberlain, A. (2013). Effects of a data-driven district reform model on state assessment outcomes. American Educational Research Journal, 50(2), 71-396. https://doi.org/10.3102/0002831212466909

Staman, L. L., Timmermans, A. C. A., \& Visscher, A. J. A. (2017). Effects of a data-based decision making intervention on student achievement. Studies In Educational Evaluation, 55, 58-67. https://doi.org/10.1016/j.stueduc.2017.07.002

Stufflebeam, D. (2003). The CIPP model for evaluation. In T. Kellaghan, D. Stufflebeam, \& L. Wingate (Eds.), International handbook of educational evaluation (Part 1) (pp. 31-62). Dordrecht: Springer.

Supovitz, J., \& Sirinides, P. (2017). The linking study: An experiment to strengthen teachers' engagement with data on teaching and learning. American Journal of Education, 124(2), 161-189. https://doi.org/10.1086/695610

Vanthienen, J., \& De Witte, K. (Eds.). (2017). Data analytics applications in education. New York: CRC Press.

van Veen, K., Zwart, R. C., \& Meirink, J. (2012). What makes teacher professional development effective? A literature review. In M. Kooy, \& K.v. Veen (Eds.), Teacher learning that matters: International perspectives (pp. 3-21). New York: Routledge.

Whitehurst, G. J. (2012). The value of experiments in education. Education Finance and Policy, 7(2), 107-123.

Wohlstetter, P., Datnow, A., \& Park, V. (2008). Creating a system for data-driven decision-making: Applying the principal-agent framework. School Effectiveness and School Improvement, 19(3), 239-259. https://doi.org/10.1080/09243450802246376

Yoon, K. S., Duncan, T., Lee, S. W., Scarloss, B., \& Shapley, K. L. (2007). Reviewing the evidence on how teacher professional development affects student achievement. Washington DC: Institute of Education Sciences (IES). 